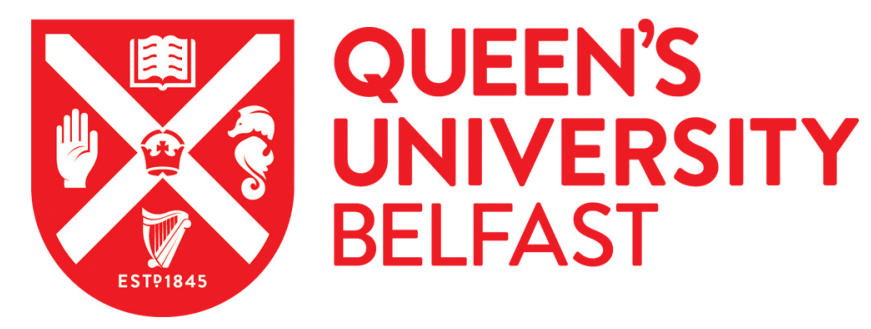

\title{
Asynchrony in key Holocene chronologies: Evidence from Irish bog pines
}

Torbenson, M. C. A., Plunkett, G., Brown, D. M., Pilcher, J. R., \& Leuschner, H. H. (2015). Asynchrony in key Holocene chronologies: Evidence from Irish bog pines. Geology, 43(9), 799-802.

https://doi.org/10.1130/G36914.1

\section{Published in:}

Geology

\section{Document Version:}

Peer reviewed version

Queen's University Belfast - Research Portal:

Link to publication record in Queen's University Belfast Research Portal

Publisher rights

(c) 2015 Geological Society of America

\section{General rights}

Copyright for the publications made accessible via the Queen's University Belfast Research Portal is retained by the author(s) and / or other copyright owners and it is a condition of accessing these publications that users recognise and abide by the legal requirements associated with these rights.

Take down policy

The Research Portal is Queen's institutional repository that provides access to Queen's research output. Every effort has been made to ensure that content in the Research Portal does not infringe any person's rights, or applicable UK laws. If you discover content in the Research Portal that you believe breaches copyright or violates any law, please contact openaccess@qub.ac.uk. 
Publisher: GSA

Journal: GEOL: Geology

DOI:10.1130/G36914.1

1 Asynchrony in key Holocene chronologies: Evidence from

2 Irish bog pines

3 Max C.A. Torbenson ${ }^{1,2^{*}}$, Gill Plunkett ${ }^{1}$, David M. Brown ${ }^{1}$, Jonathan R. Pilcher ${ }^{1}$, and

4 Hanns Hubert Leuschner ${ }^{3}$

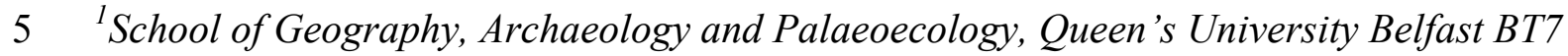

$6 \quad 1 N N$, Northern Ireland

$7 \quad{ }^{2}$ Department of Geosciences, University of Arkansas, Fayetteville, Arkansas 72701, USA

$8{ }^{3}$ Department of Palynology and Climate Dynamics, Georg-August-Universität Göttingen,

937073 Göttingen, Germany

10 *E-mail: mtorbens@uark.edu

11 ABSTRACT

12 The Greenland Ice Core Chronology 2005 (GICC05) and the radiocarbon

13 calibration curve (IntCal) are the foremost time scales used in paleoclimatic and

14 paleoenvironmental studies on the most recent 10,000 years. Due to varying and often

15 insufficient dating resolution, opportunities to test the synchrony of these two influential

16 chronologies are rare. Here we present evidence for a phase of major pine recruitment on

17 Irish bogs around $8160 \mathrm{cal}$ yr B.P. Dendrochronological dating of subfossil trees from

18 three sites reveals synchronicity in germination across the study area, indicative of a

19 regional forcing. The concurrent colonization of pine on peatland is interpreted in terms

20 of drier surface conditions and provides the first substantive proxy data in support of a

21 significant hydroclimatic change in the north of Ireland accompanying the $8.2 \mathrm{ka}$ event.

22 The date of pine establishment does not overlap with the GICC05 age range for the event, 
Publisher: GSA

Journal: GEOL: Geology

DOI: $10.1130 / \mathrm{G} 36914.1$

23 and potential lags between responses are unlikely to explain the full difference. In light of

24 recent studies highlighting a possible offset in GICC05 and IntCal dates, the Irish pine

25 record supports the notion of ice core dates being too early during the period of study. If

26 the suggested discrepancy in timing is an artifact of chronological error, it is likely to

27 have affected interpretations of previous proxy comparisons and alignments.

\section{INTRODUCTION}

29 Proxy records are a means by which we understand past climate variability and

30 validate models used to project future scenarios of climate change (Bradley, 2008).

31 Multi-proxy approaches are becoming increasingly important as they offer unrivaled

32 insights into the spatiotemporal evolution of past climatic changes (Li et al., 2010).

33 However, the temporal synchronization of records is crucial in such exercises and one of

34 the main obstacles in proxy alignment is chronological imprecision (Blaauw, 2012).

35 Wide date ranges can lead to the "sucking in" (sensu Baillie, 1991) of unrelated evidence

36 and subsequently cause wrongful attribution of shifts in a proxy record to the event of

37 interest. Radiocarbon is one of the most commonly used dating methods and also

38 provides an indirect record of past solar variability, one of the forcing mechanisms that

39 climate science tries to factor in. The Greenland ice cores are arguably the foremost

40 records of climate change over the past $100 \mathrm{k}$ yr and are regularly used in comparisons

41 with other paleoenvironmental and paleoclimatic proxies (e.g., Tinner and Lotter 2001).

42 The commonly accepted chronology for these records is the Greenland Ice Core

43 Chronology 2005 (GICC05; Vinther et al., 2006), a product developed through

44 synchronization of volcanic ash horizons present in the ice cores. 


\section{Publisher: GSA \\ Journal: GEOL: Geology \\ DOI:10.1130/G36914.1}

Both GICC05 and the radiocarbon calibration curve (IntCal; Reimer et al., 2009)

46 contain varying amounts of uncertainty throughout their spans. Recently, a number of

47 studies have highlighted the likelihood of a temporal offset between the two chronologies

48 (Lohne et al., 2013; Muscheler et al., 2014; Baillie and McAneney, 2015). These studies

49 focus on different time periods and use a variety of methodologies but the results have in

50 common that the GICC05 dates are significantly older than the radiocarbon ages for

51 supposedly contemporary periods. In order to assess fully the relationship between

52 GICC05 and IntCal, and to quantify any potential asynchrony, date comparisons from

53 throughout the records are needed but because the chronological uncertainties increase

54 with time, finding early Holocene information that will allow such analysis is rare.

55 Here we present data from three bogs in the north of Ireland that suggest an

56 unprecedented germination event of Scots pine (Pinus sylvestris L.) at ca. $8160 \mathrm{yr}$ B.P.

57 We interpret the event as the result of climatically induced drying of the bog surfaces,

58 indicative of a hydroclimatic shift that is in agreement with model outputs of the $8.2 \mathrm{ka}$

59 event, as well as other proxy evidence. The absolute date for the extra-local germination

60 is compared to the GICC05 date of the $8.2 \mathrm{ka}$ event and, in the context of previous

61 studies, we hypothesize on the synchrony of GICC05 and IntCal.

\section{METHODS AND MATERIALS}

63 Previous research stemming from a decade-long campaign of sampling Northern

64 Ireland bogs for subfossil pines culminated in the development of several local tree-ring

65 chronologies (Pilcher et al., 1995). Pine was present in the area by at least 9000 cal. yr

66 B.P., but the vast majority of collected trees fell into one of two later periods. For the

67 earlier period, an $809 \mathrm{yr}$ floating chronology was also constructed using samples $(\mathrm{n}=33)$ 
Publisher: GSA

Journal: GEOL: Geology

DOI:10.1130/G36914.1

68 from Sluggan Bog and was radiocarbon dated to the period ca. $8250-7450$ cal. yr B.P. A

69 shorter chronology from samples $(\mathrm{n}=3)$ collected at Fallahogy Bog crossdated with the

70 early Sluggan Bog chronology (269 yr overlap).

71 We investigate the temporal relationship between the inner ring dates of trees (an

72 estimate of germination dates) from Sluggan and Fallahogy bogs, in addition to

73 previously unpublished samples from Ballinderry (Fig. 1). All three are raised bogs, and

74 previous research at Sluggan and Fallahogy has shown that the earliest subfossil pines

75 grew within ombrotrophic peat (Smith, 1958; Smith and Goddard, 1991), thus at levels

76 independent of the ground water table. Pith was present in nearly all cross sections

77 (>95\%) from Sluggan Bog and Ballinderry, and the effect of potential pith offset

78 (imprecision when estimating rings to pith when pith is missing) is therefore deemed to

79 be insignificant for the purposes of this study. Materials were collected from the lowest

80 available point on the stem, and rapid growth rates ( $>2 \mathrm{~mm} / \mathrm{yr})$ during juvenile stages

81 suggest that the inner rings are close to representing true establishment. Samples were

82 processed and cross-dated according to standard dendrochronological procedures (Baillie,

83 1982) and site chronologies, representing the average annual growth at the site, were

84 constructed using ARSTAN (a tree-ring standardization program; Cook, 1985).

85 Accelerator mass spectrometry radiocarbon dating was performed on sequences of 10

86 annual growth rings from the Ballinderry chronologies, complementing high-precision

87 radiocarbon dates previously obtained from 20-yr-long samples from the Sluggan Bog

88 chronology. In total, six radiocarbon dates were used in the analysis.

89 RESULTS 
Publisher: GSA

Journal: GEOL: Geology

DOI: $10.1130 / \mathrm{G} 36914.1$

$90 \quad$ Four trees from Ballinderry construct a 374-yr-long chronology that shows highly

91 significant correlation ( $t=8.40, \mathrm{P}<0.0001,374 \mathrm{yr}$ overlap) with the record from

92 Sluggan Bog, which is corroborated by radiocarbon dates from the series that fall around

938000 cal. yr B.P. (Table DR1 in the GSA Data Repository ${ }^{1}$ ). The wiggle-matching of

94 additional radiocarbon dates from Ballinderry and Sluggan Bog allow a much narrower

95 age range $( \pm 18 \mathrm{yr})$ to be obtained than possible from conventional radiocarbon dating

96 (Fig. DR1), and enables the start of the Sluggan Bog chronology to be placed at $8268 \pm$

9718 cal yr B.P. This date supports a long-distance correlation with the German pine record

98 that places the start of the Sluggan chronology at 8277 yr B.P. $(t=5.87, \mathrm{P}<=0.0032)$.

99 The dating of the early Irish pine chronologies, and subsequently all trees included in

100 these, can now be considered absolute.

101 The first major germination phase, represented by the inner rings from eleven

102 trees, is confined to a $25 \mathrm{yr}$ window starting $116 \mathrm{yr}$ after the first year of the chronology

103 (8161 yr B.P.). Two of four trees at Ballinderry also fall within the $25 \mathrm{yr}$ window, and a

104 third tree just outside. Germination at Fallahogy occurs within two decades. Of all trees

$105(\mathrm{n}=40)$ collected from northern Irish bogs dating to the period $8500-7500$ cal. yr B.P., a

106 third of the total number of trees has an inner ring date between 8161 and $8137 \mathrm{yr}$ B.P.

107 (Fig. 2).

108 INTERPRETATION OF PINE HORIZONS

109 Subfossil material from Sluggan, Ballinderry, and Fallahogy Bogs provides

110 conclusive evidence for local presence of pine at multiple wetland sites at ca. $8160 \mathrm{yr}$

111 B.P. The pine horizon represents the greatest regeneration on record in the north of

112 Ireland, both in relative and absolute numbers. Establishment of pine on ombrotrophic 
Publisher: GSA

Journal: GEOL: Geology

DOI:10.1130/G36914.1

113 bogs has traditionally been seen as an indicator of drier local conditions (Bridge et al.,

114 1990; Eckstein et al., 2009), and bog pine remains have been used as an indicator of low

115 water-table levels (e.g., Edvardsson et al., 2012). As the bog surface becomes dry enough

116 for seedlings to survive, trees will invade the open landscape. Pine is a rapid colonizer

117 and can dominate newly available space within years of a shift to favorable conditions

118 (Richardson, 2000). Although changes in peatland hydrology are not necessarily tied to

119 climate (Swindles et al., 2012), temporal coherence over multiple hydrological systems

120 indicates an extra-local forcing.

121 A climatic impact on growing conditions on the bogs during the period is further

122 supported by a common ring-width anomaly displayed by the three site chronologies

123 wherein significant negative departures from mean growth lasting for 15-20 yr are

124 recorded from ca. $8020-8000$ yr B.P., $130 \mathrm{yr}$ after the start of the establishment episode

125 (Fig. 3). The persistent low growth is the most severe $>10$ yr period in all three

126 chronologies, and suggests a shift in climate across the north of Ireland. Within two

127 decades of the growth depression, the last of the trees at Ballinderry and Fallahogy

128 successfully germinate. After this, conditions were arguably too wet for new pines to

129 establish on the bog surfaces. Thus, suitable conditions for pine regeneration at these two

130 sites seem not to have been sustained for more than $150-175 \mathrm{yr}$.

131 The inferred dry period occurs during major climatic upheaval in the North

132 Atlantic region (Rohling and Pälike, 2005). The $8.2 \mathrm{ka}$ event is typified in the Greenland

133 ice cores by a pronounced cooling lasting 150-160 yr (Thomas et al., 2007) and abrupt

134 changes in environmental and climate proxy records from across the globe have been

135 linked to the anomaly (Morrill and Jacobsen, 2005). The British Isles experienced a sharp 
Publisher: GSA

Journal: GEOL: Geology

DOI: $10.1130 / \mathrm{G} 36914.1$

136 drop in temperature, as registered by stable isotope records (Daley et al., 2011) and

137 mollusk assemblages (Rousseau et al., 1998). A speleothem record from southwestern

138 Ireland indicates colder and drier conditions in nearby areas (Baldini et al., 2002), and

139 mires in northern Scotland experienced a pronounced shift toward dry surfaces, likely to

140 have been caused by a decrease in precipitation (Tipping et al., 2008). Modeling of the

141 event suggests that higher northern latitudes would have experienced considerable

142 decreases in precipitation (Bauer et al., 2004), and that the North Atlantic region would

143 have witnessed one of the greatest depressions (Tindall and Valdes, 2011). The

144 coinciding dry episode on Irish bogs is interpreted as a direct result of the larger climate

145 anomaly and thus provides a precise estimate of the timing of the $8.2 \mathrm{ka}$ event in this

146 region.

\section{DISCUSSION}

148 We infer that the pine horizon in the north of Ireland bogs signals a change in

149 precipitation that led to drier bog surface conditions at the time. Effective moisture levels

150 in these environments are governed by evapotranspiration, the mass balance between

151 precipitation and temperature (Lafleur et al., 2005). Proxy temperature records from

152 Ireland and Britain (Baldini et al., 2002; Daley et al., 2011) show significantly colder

153 conditions during the period and it is therefore unlikely that bogs would have experienced

154 increased evapotranspiration. A decrease in precipitation is more likely to be the forcing

155 behind the extra-local signal recorded by the subfossil pines. With supporting evidence

156 from model outputs (Bauer et al., 2004; Tindall and Valdes, 2011), we argue that the

157 hydroclimatic shift associated with the $8.2 \mathrm{ka}$ event is that forcing. 
Publisher: GSA

Journal: GEOL: Geology

DOI:10.1130/G36914.1

The earliest individual among the cohort of establishing trees has an inner-ring

159 date of $8161 \mathrm{yr}$ B.P. Although the survival of pine seedlings partly depends on their

160 current year's weather (Gunnarsson and Rydin, 1998), the peak of favorable conditions

161 and successful pine establishment are not always simultaneous due to internal bog

162 mechanisms (Kilian et al., 1995). It has been estimated that the lag between optimal

163 climate conditions and recruitment in the northern boreal zone may be up to $20-30 \mathrm{yr}$

164 (Zackrisson et al., 1995), although the response can be much more rapid (Ågren and

165 Zackrisson, 1990). In the British Isles, the climate effect on bog water level is limited to

166 sub-decadal timescales (Charman, 2007). It is therefore unlikely that the maximum

167 potential lag between a decrease in precipitation and the earliest pine establishment

168 exceeds $20 \mathrm{yr}$. Our proposed date for the hydroclimatic shift $(8171 \pm 10 \mathrm{yr})$ does not

169 overlap with the GICC05 initiation of the 8.2 ka event $(8247 \pm 47 \mathrm{yr}$ B.P.; Thomas et al.,

170 2007) and the discrepancy is unlikely to be explained by any lag between the temperature

171 and precipitation response as model outputs suggest that changes in both variables would

172 have occurred within $10 \mathrm{yr}$ of the event (Bauer et al., 2004; Tindall and Valdes 2011).

173 The pine horizon is, however, in agreement with an alternative timing of the $8.2 \mathrm{ka}$ event

174 proposed by Muscheler et al. (2004) based on the synchronization of ${ }^{10} \mathrm{Be}$ values from the

175 Greenland Ice Core Project (GRIP) ice core with the absolutely dated $\Delta^{14} \mathrm{C}$ record from

176 tree-rings. Their dating puts the start of the climate anomaly in the Greenland Ice Sheet

177 Project 2 (GISP2) ice core at $8175 \pm 30$ yr B.P. (Kobashi et al., 2007). We propose,

178 therefore, that the GICC05 chronology is overly old at this time by multiple decades.

179 Additionally, the severe growth depression recorded by all three site chronologies at

$1808020-8000$ yr B.P. (Fig. 3) could be concurrent with a secondary drop in ${ }^{18} \mathrm{O}$ values in 
Publisher: GSA

Journal: GEOL: Geology

DOI: $10.1130 / \mathrm{G} 36914.1$

181 GICC05, if GICC05 is shifted forward the several decades proposed by the discrepancy

182 in start dates for the event. Although the relationship between temperature and tree-

183 growth in this region is complicated, $P$. sylvestris in wetland areas tends to prefer warmer

184 conditions (e.g., Linderholm et al., 2002; Edvardsson et al., 2012) and the prolonged cold

185 spell would likely have had an adverse effect on ring-widths at our sites. When reviewing

186 proxy records from across the globe, Morrill and Jacobsen (2005) found the greatest

187 concentration of climate anomalies dated within the window $8100-8150$ cal. yr B.P.,

188 which lends further support for an offset between ice cores and radiocarbon-dated proxies

189 at the time.

190 The dating discrepancy indicated by our results falls in the most problematic part

191 of the Holocene GICC05, during which the ice-core chronology has a maximum counting

192 error of $2 \%$ (Rasmussen et al., 2006). It is also the period during which differences

193 between the IntCal ${ }^{14} \mathrm{C}$ and ice-core ${ }^{10} \mathrm{Be}$ values are the greatest, and where no

194 synchronization can be reached without shifting GICC05 in the direction suggested by

195 our interpretation (Muscheler et al., 2014). Records of radionuclide variations (Kobashi et

196 al., 2007; Muscheler et al., 2014) and the Irish pine data independently suggest that the

197 mean GICC05 dates are overly old by $65-75$ yr for the early Holocene.

198 Tephrochronological studies of the Vedde and Saksunarvatn ashes (western Norway)

199 suggest a similar magnitude of asynchrony $(\sim 70 \mathrm{yr})$ around the Younger Dryas boundary

200 (Lohne et al., 2013). There are also indications of more recent offsets. New radiocarbon

201 age estimates of Aniakchak II ash layers (Alaska; 3570-3410 cal yr B.P.) (Blackford et

202 al., 2014) are younger than the GICC05 date of 3590 yr B.P. \pm 1 yr B.P. for the eruption

203 (Coulter et al., 2012). Furthermore, Baillie and McAneney (2015) have suggested a 7 yr 
Publisher: GSA

Journal: GEOL: Geology

DOI: $10.1130 / \mathrm{G} 36914.1$

204 offset prior to $1400 \mathrm{yr}$. B.P. based on frost damage in tree-rings and the spacing between

205 acid spikes in the Greenland ice. These studies all indicate an asynchrony in the same

206 direction (Fig. 4), implying a systematic overestimation of the true age of the Greenland

207 ice layers. An accumulative offset would therefore seem to be explained by a bias in

208 GICC05 toward double counting of uncertain years.

\section{CONCLUSIONS}

210 Subfossil materials from bogs in the north of Ireland record an unprecedented

211 episode of pine establishment at ca. $8160 \mathrm{yr}$ B.P. Dry conditions inferred from the trees

212 are interpreted as a direct hydroclimatic response to the $8.2 \mathrm{ka}$ event, in agreement with

213 decreased precipitation suggested by other proxy records and climate model outputs. The

214 timing of pine recruitment falls outside of the GICC05 date range for the event and adds

215 to growing concerns about the synchrony between GICC05 and IntCal. Taken together,

216 the results indicate that the widely accepted chronology for Greenland ice cores may

217 contain uncertainty that falls outside the current estimated counting error. If the suggested

218 offset in dates is real it has undoubtedly had a significant impact on previous

219 interpretations of past large-scale climate dynamics and may render some conclusions

220 invalid. We believe that the data currently available warrant a frank discussion on the

221 synchrony of the main Holocene timescales and we urge the paleoclimate community to

222 address this issue. Furthermore, there is a need for additional date comparisons to be

223 undertaken in order to quantify fully the agreement of chronologies during other parts of

224 the Holocene.

225 ACKNOWLEDGMENTS 
Publisher: GSA

Journal: GEOL: Geology

DOI: $10.1130 / \mathrm{G} 36914.1$

We thank the ${ }^{14}$ Chrono Centre at Queen's University Belfast for providing the

radiocarbon dates used in this project. Parts of the study were supported by the anonymous reviewers for constructive comments.

\section{REFERENCES CITED}

233 Ågren, J., and Zackrisson, O., 1990, Age and size structure of Pinus sylvestris

234 populations on mires in central and northern Sweden: Journal of Ecology, v. 78,

$235 \quad$ p. $1049-1062$, doi:10.2307/2260951.

236 Baillie, M.G.L., 1982, Tree-ring dating and archaeology: Chicago, Illinois, The

237 University of Chicago Press, 274 p.

238 Baillie, M.G.L., 1991, Suck-in and smear - Two related chronological problems for the

239 90's: Journal of Theoretical Archaeology, v. 2, p. 12-16.

240 Baillie, M.G.L., and McAneney, J., 2015, Tree ring effects and ice core acidities clarify

241 the volcanic record of the $1^{\text {st }}$ millennium: Climate of the Past, v. 11, p. 105-114, doi:10.5194/cp-11-105-2015.

243 Baldini, J.U.L., McDermott, F., and Fairchild, I.J., 2002, Structure of the 8200-year cold

244 event revealed by a speleothem trace element record: Science, v. 296, p. 2203-2206, doi:10.1126/science.1071776.

246 Bauer, E., Ganopolski, A., and Montoya, M., 2004, Simulation of the cold climate event 2478200 years ago by meltwater outburst from Lake Agassiz: Paleoceanography, v. 19, $248 \quad$ PA3014, doi:10.1029/2004PA001030. 
Publisher: GSA

Journal: GEOL: Geology

DOI: $10.1130 / \mathrm{G} 36914.1$

249 Blaauw, M., 2012, Out of tune: the dangers of aligning proxy archives: Quaternary

$250 \quad$ Science Reviews, v. 36, p. 38-49, doi:10.1016/j.quascirev.2010.11.012.

251 Blackford, J.J., Payne, R.J., Heggen, M.P., de la Riva Caballero, A., and van der Plicht,

252 J., 2014, Age and impacts of the caldera-forming Aniakchak II eruption in western

253 Alaska: Quaternary Research, v. 82, p. 85-95, doi:10.1016/j.yqres.2014.04.013.

254 Bradley, R.S., 2008, Holocene perspectives on future climate change, in Battarbee, R.W.,

255 and Binney, H.A., eds., Natural Climate Variability and Global Warming-A

256 Holocene Perspective: Oxford, UK, Blackwell Publishing Ltd, p. 254-268.

257 Bridge, M.C., Haggart, B.A., and Lowe, J.J., 1990, The history and palaeoclimatic

258 significance of subfossil remains of Pinus sylvestris in blanket peats from Scotland:

259 Journal of Ecology, v. 78, p. 77-99, doi:10.2307/2261038.

260 Charman, D., 2007, water deficit variability controls on peatland water-table changes:

261 Implications for Holocene palaeoclimate reconstructions: The Holocene, v. 17,

262 p. 217-227, doi:10.1177/0959683607075836.

263 Cook, E.R., 1985, A time series analysis approach to tree-ring standardization [Ph.D.

264 dissertation]: Tucson, Arizona, University of Arizona, $171 \mathrm{p}$.

265 Coulter, S.E., Pilcher, J.R., Plunkett, G., Baillie, M.G.L., Hall, V.A., Steffensen, J.P.,

266 Vinther, B.M., Clausen, H.B., and Johnsen, S.J., 2012, Holocene tephras highlight

267 complexity of volcanic signals in Greenland ice cores: Journal of Geophysical

268 Research, D, Atmospheres, v. 117, doi:10.1029/2012JD017698.

269 Daley, T.J., et al., 2011, The 8200 yr B.P. cold event in stable isotope records from the

270 North Atlantic region: Global and Planetary Change, v. 79, p. 288-302,

271 doi:10.1016/j.gloplacha.2011.03.006. 
Publisher: GSA

Journal: GEOL: Geology

DOI: $10.1130 / \mathrm{G} 36914.1$

272 Eckstein, J., Leuschner, H.H., Bauerochse, A., and Sass-Klaassen, U.G.W., 2009,

273 Subfossil bog-pine horizons document climate and ecosystem changes during the

274 Mid-Holocene: Dendrochronologia, v. 27, p. 129-146,

275 doi:10.1016/j.dendro.2009.06.007.

276 Edvardsson, J., Linderson, H., Rundgren, M., and Hammarlund, D., 2012, Holocene

277 peatland development and hydrological variability inferred from bog-pine

278 dendrochronology and peat stratigraphy—A case study from southern Sweden:

279 Journal of Quaternary Science, v. 27, p. 553-563, doi:10.1002/jqs.2543.

280 Gunnarsson, U., and Rydin, H., 1998, Demography and recruitment of Scots pine on

281 raised bogs in eastern Sweden and relationships to microhabitat differentiation:

282 Wetlands, v. 18, p. 133-141, doi:10.1007/BF03161450.

283 Kilian, M.R., van der Plicht, J., and van Geel, B., 1995, Dating raised bogs: New aspets

284 of AMS ${ }^{14} \mathrm{C}$ wiggle matching, a reservoir effect and climatic change: Quaternary

285 Science Reviews, v. 14, p. 959-966, doi:10.1016/0277-3791(95)00081-X.

286 Kobashi, T., Severinghaus, J.P., Brook, E.J., Barnola, J.-M., and Grachev, A.M., 2007,

287 Precise timing and characterization of abrupt climate change 8200 years ago from air

288 trapped in polar ice: Quaternary Science Reviews, v. 26, p. 1212-1222,

289 doi:10.1016/j.quascirev.2007.01.009.

290 Lafleur, P.M., Hember, R.A., Admiral, S.W., and Roulet, N.T., 2005, Annual and

291 seasonal variability in evapotranspiration and water table at a shrub-covered bog in

292 southern Ontario, Canada: Hydrological Processes, v. 19, p. 3533-3550,

293 doi:10.1002/hyp.5842. 
Publisher: GSA

Journal: GEOL: Geology

DOI:10.1130/G36914.1

294 Li, B., Nychka, D.W., and Ammann, C.M., 2010, The value of multiproxy reconstruction

295 of past climate: Journal of the American Statistical Association, v. 105, p. 883-895,

296 doi:10.1198/jasa.2010.ap09379.

297 Linderholm, H.W., Moberg, A., and Grudd, H., 2002, Peatland pines as climate

298 indicators? A regional comparison of the climatic influence on Scots pine growth in

299 Sweden: Canadian Journal of Forest Research, v. 32, p. 1400-1410,

300 doi:10.1139/x02-071.

301 Lohne, Ø.S., Mangerud, J., and Birks, H.H., 2013, Precise ${ }^{14} \mathrm{C}$ ages of the Vedde and

302 Saksunarvatn ashes and the Younger Dryas boundaries from western Norway and

303 their comparison with the Greenland Ice Core (GICC05) chronology: Journal of

304 Quaternary Science, v. 28, p. 490-500, doi:10.1002/jqs.2640.

305 Morrill, C., and Jacobsen, R.M., 2005, How widespread were climate anomalies 8200

306 years ago?: Geophysical Research Letters, v. 32, L19701,

307 doi:10.1029/2005GL023536.

308 Muscheler, R., Beer, J., and Vonmoos, M., 2004, Causes and timing of the $8200 \mathrm{yr}$ B.P.

309 event inferred from the comparison of GRIP ${ }^{10} \mathrm{Be}$ and the tree ring $\delta{ }^{14} \mathrm{C}$ record:

310 Quaternary Science Reviews, v. 23, p. 2101-2111,

311 doi:10.1016/j.quascirev.2004.08.007.

312 Muscheler, R., Adolphi, F., and Knudsen, M.F., 2014, Assessing the differences between

313 the IntCal and Greenland ice-core time scales for the last 14,000 years via the

314 common cosmogenic radionuclide variations: Quaternary Science Reviews, v. 106,

315 p. 81-87, doi:10.1016/j.quascirev.2014.08.017. 
Publisher: GSA

Journal: GEOL: Geology

DOI: $10.1130 / \mathrm{G} 36914.1$

316 Pilcher, J.R., Baillie, M.G.L., Brown, D.M., McCormac, F.G., MacSweeney, P.B., and

317 McLawrence, A.S., 1995, Dendrochronology of subfossil pine in the north of

318 Ireland: Journal of Ecology, v. 83, p. 665-671, doi:10.2307/2261634.

319 Rasmussen, S.O., et al., 2006, A new Greenland ice core chronology for the last glacial

320 termination: Journal of Geophysical Research, D, Atmospheres, v. 111,

321 doi:10.1029/2005JD006079.

322 Reimer, P.J., et al., 2009, INTCAL09 and MARINE09 radiocarbon age calibration curves

$3230-50,000$ years cal B.P: Radiocarbon, v. 51, p. 1111-1150.

324 Richardson, D.M., 2000, Ecology and Biogeography of Pinus: Cambridge, UK,

325 Cambridge University Press, 490 p.

326 Rohling, E.J., and Pälike, H., 2005, Centennial-scale climate cooling with a sudden cold

327 event around 8,200 years ago: Nature, v. 434, p. 975-979, doi:10.1038/nature03421.

328 Rousseau, D.-D., Preece, R., and Limondin-Lozouet, N., 1998, British late glacial and

329 Holocene climatic history reconstructed from land snail assemblages: Geology,

330 v. 26, p. 651-654, doi:10.1130/0091-7613(1998)026<0651:BLGAHC $>2.3 . C O ; 2$.

331 Smith, A.G., 1958, Pollen analytical investigations of the mire at Fallahogy Td. Co.

332 Derry: Proceedings of the Royal Irish Academy, v. 59, p. 329-343.

333 Smith, A.G., and Goddard, I.C., 1991, A 12500 year record of vegetational history at

334 Sluggan Bog, Co. Antrim, N. Ireland (incorporating a pollen zone scheme for the

335 non-specialist): The New Phytologist, v. 118, p. 167-187, doi:10.1111/j.1469-

336 8137.1991.tb00576.x. 
Publisher: GSA

Journal: GEOL: Geology

DOI:10.1130/G36914.1

337 Swindles, G.T., Morris, P.J., Baird, A.J., Blaauw, M., and Plunkett, G., 2012,

338 Ecohydrological feedbacks confound peat-based climate reconstructions:

339 Geophysical Research Letters, v. 39, L11401, doi:10.1029/2012GL051500.

340 Thomas, E.R., Wolff, E.W., Mulvaney, R., Steffensen, J.P., Johnsen, S.J., Arrowsmith,

341 C., White, J.W.C., Vaughn, B., and Popp, T., 2007, The 8.2 ka event from Greenland

342 ice cores: Quaternary Science Reviews, v. 26, p. 70-81,

343 doi:10.1016/j.quascirev.2006.07.017.

344 Tindall, J.C., and Valdes, P.J., 2011, Modeling the 8.2ka event using coupled

345 atmosphere-ocean GCM: Global and Planetary Change, v. 79, p. 312-321,

346 doi:10.1016/j.gloplacha.2011.02.004.

347 Tinner, W., and Lotter, A.F., 2001, Central European vegetation response to abrupt

348 climate change at 8.2 ka: Geology, v. 29, p. 551-554, doi:10.1130/0091-

349 7613(2001)029<0551:CEVRTA >2.0.CO;2.

350 Tipping, R., Ashmore, P., Davies, A.L., Haggart, B.A., Moir, A., Newton, A., Sands, R.,

351 Skinner, T., and Tisdall, E., 2008, Prehistoric Pinus woodland dynamics in an upland

352 landscape in northern Scotland: The roles of climate change and human impact:

353 Vegetation History and Archaeobotany, v. 17, p. 251-267, doi:10.1007/s00334-007-

$354 \quad 0120-z$.

355 Vinther, B.M., et al., 2006, A synchronized dating of three Greenland ice cores

356 throughout the Holocene: Journal of Geophysical Research, D, Atmospheres, v. 111,

357 p. D13102, doi:10.1029/2005JD006921. 
Publisher: GSA

Journal: GEOL: Geology

DOI: $10.1130 / \mathrm{G} 36914.1$

358 Zackrisson, O., Nilsson, M.-C., Steijlen, I., and Hörnberg, G., 1995, Regeneration pulses

359 and climate-vegetation interactions in nonpyrogenic boreal Scots pine stands: Journal

360 of Ecology, v. 83, p. 469-483, doi:10.2307/2261600.

\section{FIGURE CAPTIONS}

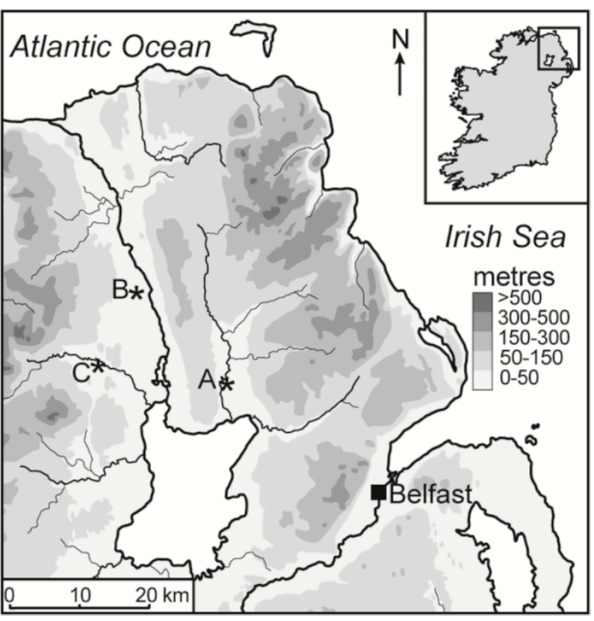

363 Figure 1. Locations of where samples used in this study were collected. A—Sluggan Bog

$364\left(54^{\circ} 46^{\prime} \mathrm{N}, 6^{\circ} 18^{\prime} \mathrm{W}\right), \mathrm{B}-$ Fallahogy $\left(54^{\circ} 54^{\prime} \mathrm{N}, 6^{\circ} 34^{\prime} \mathrm{W}\right), \mathrm{C}-$ Ballinderry $\left(54^{\circ} 48^{\prime} \mathrm{N}\right.$,

$\left.3656^{\circ} 39^{\prime} \mathrm{W}\right)$.

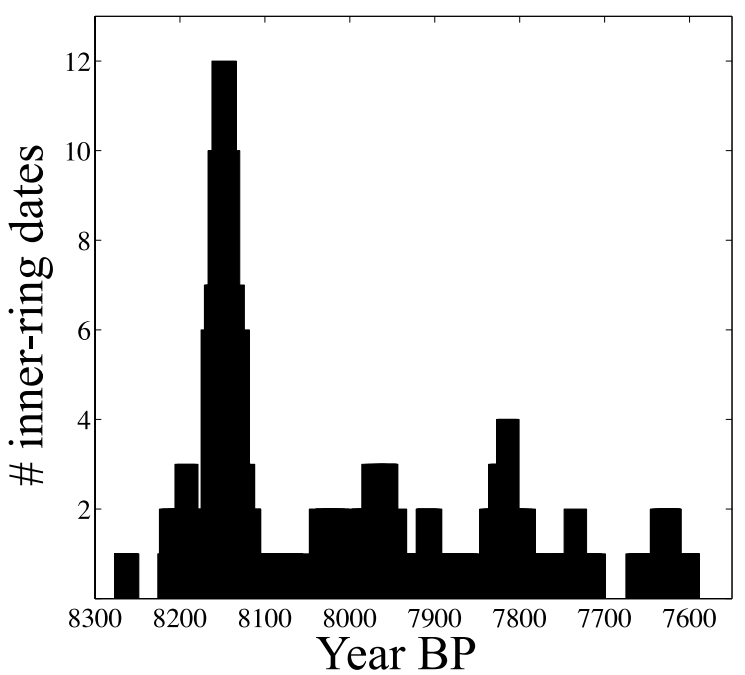

367 Figure 2. Histogram of inner-ring dates of subfossil pines from three bogs in the north of

368 Ireland. The data are plotted with running bin-sizes of $35 \mathrm{yr}$ to $20 \mathrm{yr}$ to avoid sample bias. 
Publisher: GSA

Journal: GEOL: Geology

DOI: $10.1130 / \mathrm{G} 36914.1$

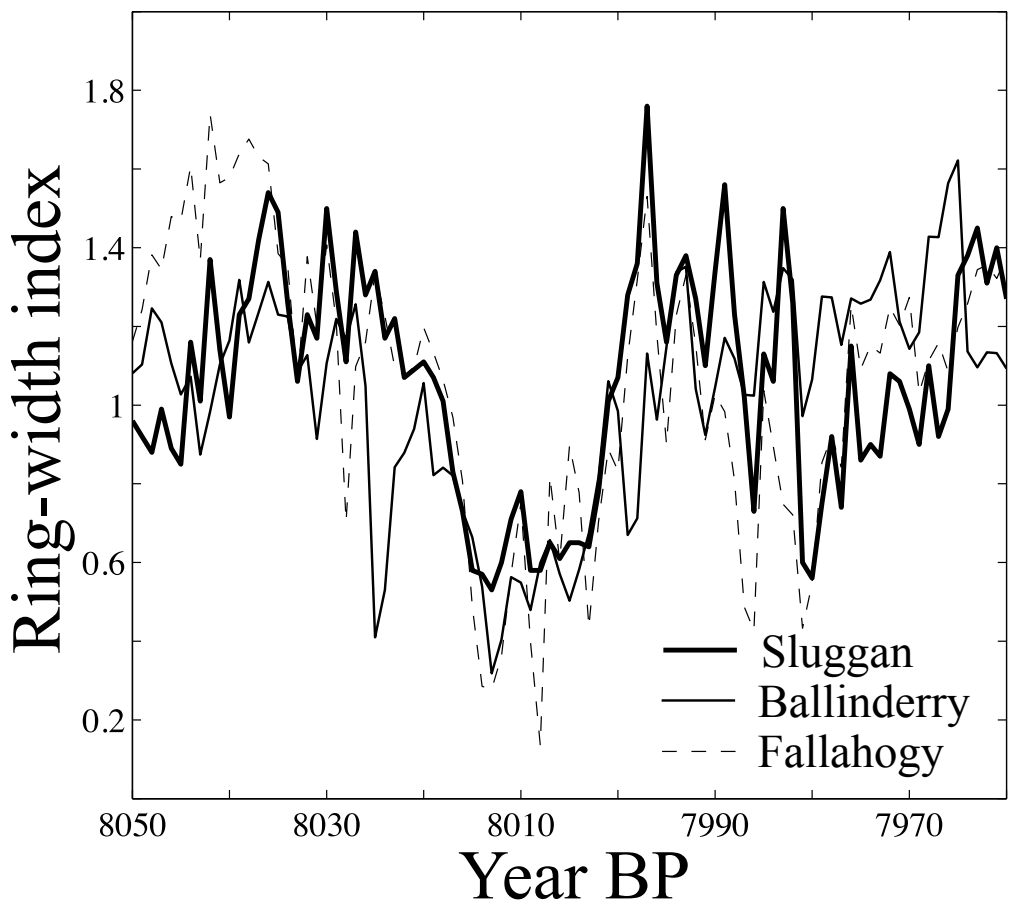

370 Figure 3. Ring-widths for the period 8050-7980 yr B.P. from Sluggan Bog, Fallahogy

371 (Pilcher et al., 1995), and Ballinderry bog-pine chronologies in the north of Ireland. A

372 pronounced period of low-growth at all sites is evident from 8020 to $8000 \mathrm{yr}$ B.P.

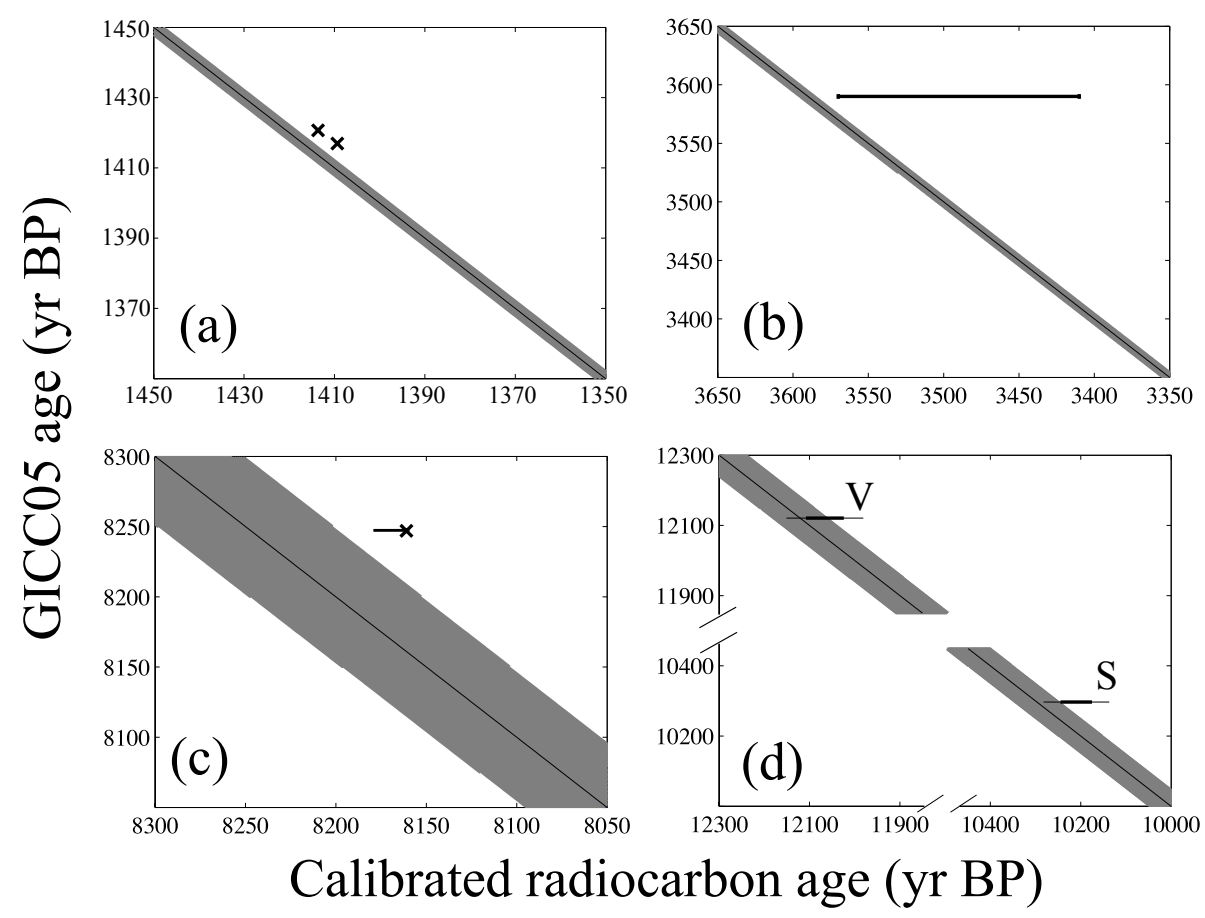

Page 18 of 19 
Publisher: GSA

Journal: GEOL: Geology

DOI: $10.1130 / \mathrm{G} 36914.1$

374 Figure 4. Comparison of dates from Greenland Ice Core Chronology 2005 (GICC05) and

375 terrestrial records. A: Volcanic eruptions in $1414 \mathrm{yr}$ B.P. and 1410-1409 yr B.P. (Baillie

376 and McAneney, 2015). B: Aniakchak II eruption (Alaska; Blackford et al., 2014). C: The

3778.2 ka event (this study). D: Saksarnuvatn and Vedde ash eruptions (Norway; Lohne et

378 al., 2013). Gray bands represent the counting error associated with the GICC05 at any

379 given year of the record. X's represent absolute dates and black horizontal lines estimated

380 uncertainty or radiocarbon age ranges $(2 \sigma)$, with $1 \sigma$ in wider line-width for $\mathrm{D}$.

381

$382{ }^{1}$ GSA Data Repository item 2015xxx, xxxxxxxx, is available online at

383 www.geosociety.org/pubs/ft2015.htm, or on request from editing@geosociety.org or

384 Documents Secretary, GSA, P.O. Box 9140, Boulder, CO 80301, USA. 